\title{
Biological and molecular interplay between two viruses and powdery and downy mildews in two grapevine cultivars
}

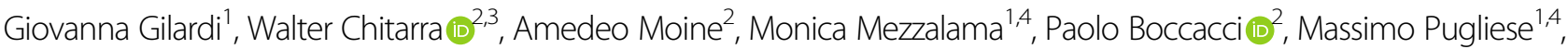 \\ Maria Lodovica Gullino ${ }^{1,4}$ and Giorgio Gambino (1) ${ }^{2}$
}

\begin{abstract}
Grapevine may be affected simultaneously by several pathogens whose complex interplay is largely unknown. We studied the effects of infection by two grapevine viruses on powdery mildew and downy mildew development and the molecular modifications induced in grapevines by their multiple interactions. Grapevine fanleaf virus (GFLV) and grapevine rupestris stem pitting-associated virus (GRSPaV) were transmitted by in vitro-grafting to Vitis vinifera cV Nebbiolo and Chardonnay virus-free plantlets regenerated by somatic embryogenesis. Grapevines were then artificially inoculated in the greenhouse with either Plasmopara viticola or Erysiphe necator spores. GFLV-infected plants showed a reduction in severity of the diseases caused by powdery and downy mildews in comparison to virus-free plants. GFLV induced the overexpression of stilbene synthase genes, pathogenesis-related proteins, and influenced the genes involved in carbohydrate metabolism in grapevine. These transcriptional changes suggest improved innate plant immunity, which makes the GFLV-infected grapevines less susceptible to other biotic attacks. This, however, cannot be extrapolated to GRSPaV as it was unable to promote protection against the fungal/oomycete pathogens. In these multiple interactions, the grapevine genotype seemed to have a crucial role: in 'Nebbiolo', the virus-induced molecular changes were different from those observed in 'Chardonnay', suggesting that different metabolic pathways may be involved in protection against fungal/oomycete pathogens. These results indicate that complex interactions do exist between grapevine and its different pathogens and represent the first study on a topic that still is largely unexplored.
\end{abstract}

\section{Introduction}

Grapevine (Vitis vinifera L.) is one of the most economically important and widespread fruit crops in the world. In all viticultural regions, it is affected (often simultaneously) by several pathogens, such as fungi, oomycota, phytoplasma, and viruses, which induce serious damage to the plants with consequent high economic $\operatorname{losses}^{1}$. Among these biotic agents, viruses represent a widespread class of pathogens in all grapevine species.

\footnotetext{
Correspondence: Giorgio Gambino (giorgio.gambino@ipsp.cnr.it)

${ }^{1}$ Centre of Competence for the Innovation in the Agro-Environmental sector (AGROINNOVA), University of Torino, Largo Paolo Braccini 2, 10095 Grugliasco, Italy

${ }^{2}$ Institute for Sustainable Plant Protection, National Research Council (IPSP-

CNR), Strada delle Cacce 73, 10135 Torino, Italy

Full list of author information is available at the end of the article
}

Thanks to deep sequencing technologies and the subsequent discovery of new viruses, more than 80 virus species have been identified in grapevine ${ }^{2}$. Among these, about half are recognized as agents of 'major diseases' in terms of economic relevance ${ }^{3}$, while others may not show clear, typical symptoms possibly also for mixed infections with other viruses in the same plant. Two well known and widespread viruses are grapevine rupestris stem pittingassociated virus (GRSPaV) and grapevine fanleaf virus (GFLV). GRSPaV is a member of the genus Foveavirus, family Betaflexiviridae, generally associated with "Rupestris Stem Pitting", a disorder of the "Rugose Wood complex" ${ }^{3}$, and it usually infects $V$. vinifera cultivars in a latent state. GFLV is a member of the genus Nepovirus in the family Secoviridae ${ }^{4}$ responsible for the complex of

\section{(c) The Author(s) 2020}

(c) (i) Open Access This article is licensed under a Creative Commons Attribution 4.0 International License, which permits use, sharing, adaptation, distribution and reproduction c. in any medium or format, as long as you give appropriate credit to the original author(s) and the source, provide a link to the Creative Commons license, and indicate if changes were made. The images or other third party material in this article are included in the article's Creative Commons license, unless indicated otherwise in a credit line to the material. If material is not included in the article's Creative Commons license and your intended use is not permitted by statutory regulation or exceeds the permitted use, you will need to obtain permission directly from the copyright holder. To view a copy of this license, visit http://creativecommons.org/licenses/by/4.0/. 
'Grapevine infectious degeneration' and is one of the most harmful and economically impacting grapevine-virus diseases worldwide ${ }^{3}$. Several studies have analysed the ecophysiological, molecular, and biochemical modifications induced by viruses in grapevine $e^{5-10}$, which can then be regarded as a model to study plant-virus interactions in fruit plants and other woody species ${ }^{11}$. In recent years, it has become increasingly evident that plant-virus interactions are not limited to a simple reaction to pathogen infection and that they can shift from antagonist to mutualistic or beneficial responses to environmental changes ${ }^{12,13}$. Viruses can increase the tolerance of plants to drought and cold stress ${ }^{14}$, high soil temperatures ${ }^{15}$, and bacterial pathogens ${ }^{16,17}$. V. vinifera cv 'Bosco' infected by GRSPaV showed greater tolerance to water stress than virus-free plants ${ }^{18}$. The detrimental effects of grapevine leafroll associated virus-3 (GLRaV-3) have been extensively demonstrated in grapevine ${ }^{5,8}$ although Repetto et al. ${ }^{19}$ reported that GLRaV-3-infected grapevines displayed an increased resistance to downy mildew (DM) caused by Plasmopara viticola. All together these studies show that plant-virus interactions are more complex than expected and a deeper understanding of these interactions would be warranted, considering the plant as a holobiont in which micro- and macrobiomes interact with the environment as a unique organism ${ }^{20}$.

If viruses are the most numerous and widespread class of pathogens in all Vitis spp., doubtless, fungal/oomyceteassociated diseases represent, in terms of economic and environmental impact, the main adversity in the vineyard, which can lead to a total loss of production if not efficiently controlled. In European grape-growing regions, the most important pathogens significantly impacting crop quality and quantity are DM and powdery mildew (PM). DM is caused by the obligate biotrophic oomycete P. viticola, introduced into Europe from North America in the late 19th century ${ }^{21}$. DM affects the leaves and berries under warm and humid environmental conditions, reducing grape yield and negatively impacting the quality of berries and the aging ability of wine ${ }^{1,22}$. PM is caused by the obligate biotrophic fungus Erysiphe necator, a polycyclic fungus infecting all green tissues with grey-white mycelia on the surface, leading to significant losses in yield and quality, as well as fruit and wine characteristics $^{1,23}$. Management of these diseases in the vineyard implicates significant economic and environmental costs, to such an extent that grapevines are one of the most frequently sprayed crops ${ }^{24-26}$. The European Commission has already expressed its recommendation to reduce the use of several chemical products (Directive 2009/128/EC), including copper salts (CE no. 354/2014). Consequently, in recent years, several studies have been carried out to investigate the effectiveness of more environmentally friendly products, such as several microorganisms, resistance inducers, biostimulants, and biofungicides ${ }^{27-30}$. However, so far, no studies have been reported on the induction of resistance to PM by viruses while only a few studies have been carried out on $\mathrm{DM}^{19}$.

The aim of this work was to study the effects of GRSPaV and GFLV on DM and PM incidence and severity and the systemic molecular modifications induced in grapevines by these multiple interactions under controlled greenhouse conditions.

\section{Results \\ Virus identification and plant material}

In the present study the interactions among viruses, DM and PM were evaluated on 'Chardonnay' and 'Nebbiolo' grapevine cultivar. Immature anthers of both genotypes were collected in May 2016 and cultured in an inductive medium for embryogenesis to obtain virus-free plants, as confirmed by RT-PCR. A single line per cultivar regenerated from somatic embryos was multiplied in vitro, thus supplying the virus-free controls (NE_CTR and CH_CTR) for subsequent experiments (Supplementary Fig. S1).

A 'Nebbiolo' plant originally infected only by GFLV and GRSPaV was previously subjected to sanitation techniques that eliminated GFLV in some explants and GRSPaV in other explants, thus obtaining lines still infected by only one of these two viruses. To identify the GRSPaV variant present in infected plant, the viral RNA-dependent RNA polymerase (RdRP) was amplified by RT-PCR ${ }^{31}$ and sequenced. The GRSPaV isolate (GRSPaV_NE, NCBI accession number MN889892) belongs to the phylogenetic group designed as GRSPaV-SG1 (Supplementary Fig. S2a), following the classification in the eight major groups suggested by Meng and Rowhani ${ }^{32}$. The GFLV variant infecting 'Nebbiolo' was identified by RT-PCR ${ }^{33}$ by amplification of the RdRP sequence in RNA1 and by sequencing. The GFLV isolate (GFLV_NE, NCBI accession number MN889891) grouped together in the cluster IB with isolates from Canada and South Africa (Supplementary Fig. S2b).

'Nebbiolo' plants infected by GRSPaV or GFLV were then used as "green rootstocks" for the transmission of these viruses through in vitro grafting in virus-free lines of 'Chardonnay' and 'Nebbiolo', used as scions. One month after grafting, viral diagnoses confirmed the transmission of the viruses and the infected scions of 'Chardonnay' and 'Nebbiolo' were removed from the graft and multiplied in vitro becoming the virus-infected treatment (NE_GRSPaV, NE_GFLV, CH_GRSPaV, and CH_GFLV) for subsequent experiments (Supplementary Fig. S1).

\section{Development of powdery and downy mildews}

Virus-free and infected plants (eight plants per treatment) were grown in the glasshouse and, after 2 months, artificially inoculated with $P$. viticola or $E$. necator for the 
Table 1 Mean disease severity (percentages of affected leaf area) and mean disease incidence (percentage of affected leaves) of 'Chardonnay' (CH) and 'Nebbiolo' (NE) artificially inoculated with Plasmopara viticola and Erysiphe necator at the end of trial 1. NE_CTR, CH_CTR: virus-free plants; NE_GRSPaV, CH_GRSPaV: GRSPaV-infected plants; NE_GFLV, CH_GFLV: GFLV-infected plants. Statistical significance values for the factors 'genotype', 'virus' and their interaction (genotype $X$ virus) for disease severity and disease incidence are reported

\begin{tabular}{|c|c|c|c|c|c|}
\hline \multirow[b]{2}{*}{ Source of variance } & & \multicolumn{2}{|l|}{ Plasmopara viticola } & \multicolumn{2}{|l|}{ Erysiphe necator } \\
\hline & & Disease severity \% & Disease incidence \% & Disease severity \% & Disease incidence $\%$ \\
\hline \multirow[t]{3}{*}{ Genotype } & $\mathrm{CH}$ & $9.17 \pm 3.74 b^{a}$ & $59.94 \pm 15.62 b$ & $3.72 \pm 2.67 \mathrm{a}$ & $44.86 \pm 18.23 \mathrm{a}$ \\
\hline & $\mathrm{NE}$ & $4.83 \pm 4.85 \mathrm{a}$ & $38.31 \pm 17.69 a$ & $6.36 \pm 4.05 b$ & $62.39 \pm 15.67 b$ \\
\hline & $p$ value & $<0.001$ & $<0.001$ & 0.042 & 0.019 \\
\hline \multirow[t]{4}{*}{ Virus } & CTR & $10.96 \pm 1.69 c$ & $50.34 \pm 7.92 b$ & $7.28 \pm 1.3 b$ & $58.31 \pm 13.96 \mathrm{a}$ \\
\hline & GRSPaV & $6.06 \pm 0.99 b$ & $52.62 \pm 4.70 \mathrm{~b}$ & $4.87 \pm 4.86 \mathrm{ab}$ & $58.47 \pm 22.00 \mathrm{a}$ \\
\hline & GFLV & $3.45 \pm 1.09 \mathrm{a}$ & $35.56 \pm 9.12 \mathrm{a}$ & $2.70 \pm 0.7 \mathrm{a}$ & $42.04 \pm 16.53 a$ \\
\hline & $p$ value & $<0.001$ & 0.015 & 0.030 & 0.157 \\
\hline \multirow[t]{7}{*}{ Genotype*Virus } & $\mathrm{CH}$ _CTR & $13.11 \pm 0.91 \mathrm{c}$ & $65.04 \pm 10.83 b$ & $5.56 \pm 1.39 \mathrm{ab}$ & $50.10 \pm 6.76 a b$ \\
\hline & CH_GRSPaV & $7.38 \pm 1.53 \mathrm{a}-\mathrm{c}$ & $60.96 \pm 6.12 b$ & $3.60 \pm 1.06 \mathrm{ab}$ & $48.26 \pm 8.28 a b$ \\
\hline & CH_GFLV & $6.27 \pm 0.42 \mathrm{a}-\mathrm{c}$ & $56.84 \pm 6.96 b$ & $1.50 \pm 0.84 \mathrm{a}$ & $32.22 \pm 13.48 \mathrm{a}$ \\
\hline & NE_CTR & $7.87 \pm 2.59 \mathrm{bc}$ & $38.57 \pm 8.80 a b$ & $9.00 \pm 1.88 b$ & $66.53 \pm 4.81 \mathrm{ab}$ \\
\hline & NE_GRSPaV & $5.00 \pm 1.22 \mathrm{ab}$ & $45.94 \pm 5.65 a b$ & $6.42 \pm 2.46 \mathrm{ab}$ & $71.23 \pm 10.52 b$ \\
\hline & NE_GFLV & $0.63 \pm 0.32 \mathrm{a}$ & $14.29 \pm 6.18 \mathrm{a}$ & $3.62 \pm 0.81 a$ & $49.43 \pm 1.84 a b$ \\
\hline & $p$ value & 0.047 & 0.001 & 0.041 & 0.052 \\
\hline
\end{tabular}

aLowercase letters denote significant differences attested by Tukey's honestly significant difference (HSD) test $(p \leq 0.05)$. Standard errors are indicated

first trial of the experiment (June 2018). The percentage of affected leaves and the percentage of affected leaf area, i.e. disease incidence (DI) and severity (DS), respectively, were evaluated. At the final assessment, higher levels of downy mildew DS were observed in 'Chardonnay' compared to 'Nebbiolo', whereas in plants infected by $E$. necator, 'Chardonnay' appeared to be more tolerant than 'Nebbiolo' to PM. Plant genotype, virus, and their interaction significantly $(p \leq 0.05)$ influenced the DI and the DS caused by both pathogens. GFLV-infected plants showed lower downy mildew DS compared to virus-free plants, while GRSPaV-infected plants showed a DS not significantly different from CTR, with intermediate values between virus-free and GFLV-infected plants (Table 1). A similar trend was observed on plants artificially inoculated with $E$. necator. The genotype and virus interactions $(G \times$ $V)$ were significant, resulting in significant lower values of DS in NE_GFLV compared to CTR for both fungal/ oomycete pathogens (Table 1).

The trends of susceptibility to PM and DM were confirmed in the second trial conducted in summer 2019, where eight plants were inoculated with P. viticola or $E$. necator for each thesis (Table 2). 'Chardonnay' was consistently shown to be more susceptible to DM and less susceptible to PM than 'Nebbiolo'. The GFLV-infected plants showed significantly lower DS for both pathogens and a lower DI for PM compared to CTR when the virus was considered as a source of variance. Interestingly, GRSPaV-infected plants showed, for DM, higher DS than GFLV-infected plants (Table 2). In plants inoculated with E. necator, the GFLV-infected plants (of both cultivars) were more tolerant to PM than virus-free controls resulting in lower DS. A similar trend was observed for DI, where CH_GFLV plants showed the significantly lowest values (Table 2).

\section{Virus titre}

Virus titre was monitored in the second trial in 2019 by quantitative real-time RT-PCR (RT-qPCR) in leaf tissue immediately before fungal/oomycete inoculation (T0) and at the end of experiments ( $\mathrm{Tf}$ ), and was calculated as the relative expression ratio to the virus titre in 'Nebbiolo' at T0. GRSPaV concentration in 'Chardonnay' and 'Nebbiolo' was similar at T0 and decreased significantly at Tf (Supplementary Fig. S3). Similarly, the concentration of GFLV decreased considerably at Tf, but its level at T0 and Tf in 'Nebbiolo' were 5-6 times lower than in 'Chardonnay'; the statistical analysis revealed a significant effect of genotype, time, and their interaction (Supplementary Fig. S3). 
Table 2 Mean disease severity (percentages of affected leaf area) and mean disease incidence (percentage of affected leaves) of 'Chardonnay' (CH) and 'Nebbiolo' (NE) artificially inoculated with Plasmopara viticola and Erysiphe necator at the end of trial 2. NE_CTR, CH_CTR: virus-free plants; NE_GRSPaV, CH_GRSPaV: GRSPaV-infected plants; NE_GFLV, CH_GFLV: GFLV-infected plants. Statistical significance values for the factors 'genotype', 'virus' and their interaction (genotype $X$ virus) for disease severity and disease incidence are reported

\begin{tabular}{|c|c|c|c|c|c|}
\hline \multirow[b]{2}{*}{ Source of variance } & & \multicolumn{2}{|l|}{ Plasmopara viticola } & \multicolumn{2}{|l|}{ Erysiphe necator } \\
\hline & & Disease severity \% & Disease incidence \% & Disease severity \% & Disease incidence \% \\
\hline \multirow[t]{2}{*}{ Genotype } & $\mathrm{CH}$ & $21.12 \pm 2.31 b^{a}$ & $65.89 \pm 12.42 \mathrm{a}$ & $4.39 \pm 4.13 \mathrm{a}$ & $43.71 \pm 24.77 \mathrm{a}$ \\
\hline & $\mathrm{NE}$ & $11.90 \pm 1.73 \mathrm{a}$ & $57.23 \pm 20.17 \mathrm{a}$ & $6.78 \pm 4.11 \mathrm{a}$ & $64.12 \pm 18.25 b$ \\
\hline$p$ value & & 0.004 & 0.998 & 0.061 & 0.021 \\
\hline \multirow[t]{3}{*}{ Virus } & CTR & $18.26 \pm 2.33 b$ & $55.41 \pm 19.35 \mathrm{a}$ & $8.35 \pm 1.02 c$ & $63.09 \pm 5.48 b$ \\
\hline & GRSPaV & $22.09 \pm 3.39 b$ & $68.51 \pm 18.33 a$ & $5.33 \pm 0.99 b$ & $53.65 \pm 5.31 b$ \\
\hline & GFLV & $9.78 \pm 1.13 \mathrm{a}$ & $60.43 \pm 11.47 a$ & $1.64 \pm 0.46 \mathrm{a}$ & $31.58 \pm 6.56 a$ \\
\hline$p$ value & & 0.006 & 0.078 & $<0.001$ & 0.001 \\
\hline \multirow[t]{6}{*}{ Genotype*Virus } & $\mathrm{CH} \mathrm{C}_{-} \mathrm{TR}$ & $23.38 \pm 2.35 b c$ & $67.60 \pm 5.43 a b$ & $6.98 \pm 1.56 b c$ & $50.99 \pm 8.30 b$ \\
\hline & CH_GRSPaV & $25.58 \pm 4.63 c$ & $66.70 \pm 4.83 a b$ & $4.95 \pm 1.45 \mathrm{a}-\mathrm{c}$ & $57.92 \pm 8.48 b$ \\
\hline & CH_GFLV & $11.71 \pm 1.99 a b$ & $59.60 \pm 3.66 a b$ & $0.70 \pm 0.20 a$ & $15.98 \pm 3.39 a$ \\
\hline & NE_CTR & $11.09 \pm 1.44 a b$ & $50.14 \pm 5.52 \mathrm{a}$ & $9.72 \pm 1.18 c$ & $73.67 \pm 5.15 b$ \\
\hline & NE_GRSPaV & $17.20 \pm 4.58 b c$ & $78.85 \pm 6.94 b$ & $5.71 \pm 1.46 \mathrm{a}-\mathrm{c}$ & $49.38 \pm 6.66 b$ \\
\hline & NE_GFLV & $8.18 \pm 0.97 a$ & $59.60 \pm 5.97 a b$ & $2.69 \pm 0.73 a b$ & $47.18 \pm 9.69 b$ \\
\hline$p$ value & & 0.001 & 0.033 & $<0.001$ & $<0.001$ \\
\hline
\end{tabular}

aLowercase letters denote significant differences attested by Tukey's honestly significant difference (HSD) test $(p \leq 0.05)$. Standard errors are indicated

\section{Molecular interactions between viruses and powdery and downy mildews}

The expression of 15 genes representative of the most important molecular pathways involved in the response of biotic agents in grapevine (Supplementary Table S1) was analysed by RT-qPCR, in leaves collected in the second trial in 2019. To evaluate the viral and fungal/oomycete-mediated systemic responses in virus-infected and fungal/oomyceteinoculated plants, asymptomatic leaves were collected.

Stilbene synthases are a class of genes of the phenylpropanoid metabolism and are strongly involved in plant responses to environmental stresses, and in grapevine $V \nu S T S 48, V v S T S 16$, and VvSTS19 (Fig. 1) are involved in the response to fungal pathogens ${ }^{34}$. All three genes were overexpressed at $\mathrm{Tf}$ and expression levels systemically induced by $E$. necator (Tf_EN) were much higher than those observed after $P$. viticola (Tf_PV) inoculation (Fig. 1). A genotype effect was not observed in the expression of these three genes, while a significant interaction $\mathrm{G} \times \mathrm{V}$ was reported after $E$. necator inoculation with high expression in virus-infected plants of 'Chardonnay' (CH_GRSPaV_Tf and CH_GFLV_Tf) (Fig. 1, Supplementary Table S2). Noteworthy, the inoculation of 'Chardonnay' with E. necator did not seem to be sufficient to activate transcription of these stilbene synthases in the virus-free samples (CH_CTR) (Fig. 1).
The expression of chalcone synthase $(V \nu C H S)$ at $\mathrm{Tf}$ was influenced by fungal/oomycete inoculation. After inoculation with $E$. necator, transcription was reduced, whereas in the presence of $P$. viticola, we observed a significant increase in gene expression (Fig. 1, Supplementary Table S2). A significant interaction between genotype and time (G x T) after $P$. viticola inoculation showed an increase in $V \nu C H S$ expression in 'Nebbiolo' at Tf (Supplementary Table S3). Interestingly, the expression data of $V v S T S s$ and $V \nu C H S$ confirmed the opposite transcriptional regulation trend; high expression of VvSTSs at Tf_EN corresponded to the downregulation of $V \nu C H S$, as well as lower expression of VvSTS19 in 'Nebbiolo' Tf_PV compared to 'Chardonnay', which corresponds to an increase in $V \nu C H S$ expression under the same conditions (Fig. 1).

The expression of Pathogenesis related protein 1 $(V v P R 1)$ and Beta-1,3-glucanase (VvBgluc), defenserelated genes involved in the response to several biotic factors, was significantly affected by all three factors, namely genotype, virus, time, and their respective interactions (Fig. 2, Supplementary Table S2). They were generally upregulated in 'Nebbiolo' at T0 and showed an interesting $\mathrm{G} \times \mathrm{V}$ interaction with a progressive increase in the expression of NE_GRSPaV_T0 and NE_GFLV_T0 (Fig. 2, Supplementary Table S2). At Tf, expression was stable in 'Chardonnay', while in 'Nebbiolo', it decreased 


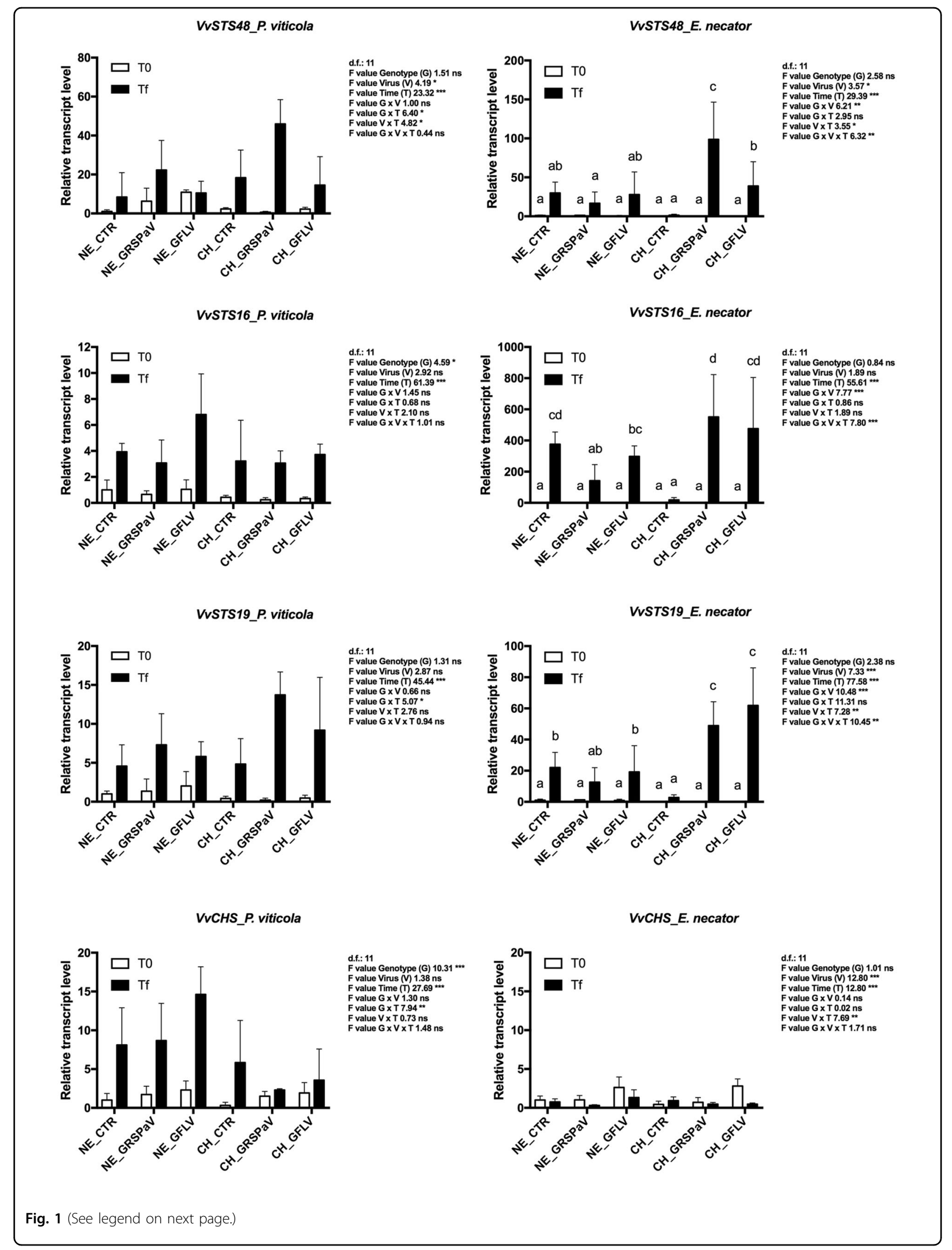


(see figure on previous page)

Fig. 1 Relative expression levels of VvSTS48 (VIT 16s0100g01200), VvSTS16 (VIT 16s0100g00920), VvSTS19 (VIT 16s0100g00750), and VvCHS (VIT_05s0136g00260) measured by quantitative reverse transcription-polymerase chain reaction (RT-qPCR). Samples were collected before inoculation with P. viticola or E. necator (TO) and at the end of experiments (Tf). RT-qPCR signals were normalized to VVAct and VVUBI transcripts. NE_CTR, CH_CTR: virus-free plants; NE_GRSPaV, CH_GRSPaV: GRSPaV-infected plants; NE_GFLV, CH_GFLV: GFLV-infected plants. Data are presented as the mean \pm standard deviation $(\mathrm{SD})(\mathrm{n}=3)$. Lowercase letters denote significant differences attested by Tukey's honestly significant difference (HSD) test $(p \leq 0.05)$

VvPR1_P. viticola

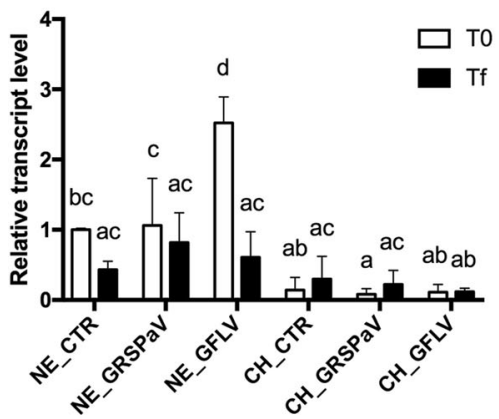

VvMLO6_P. viticola

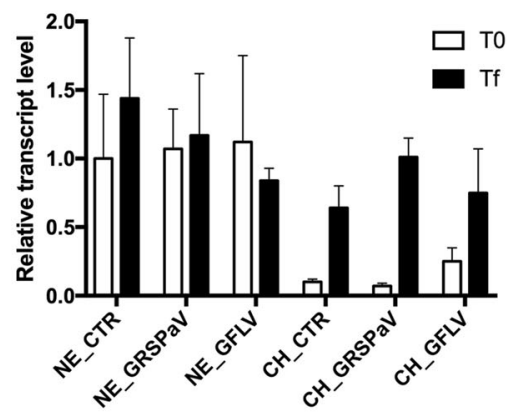

VvBGluc_P. viticola

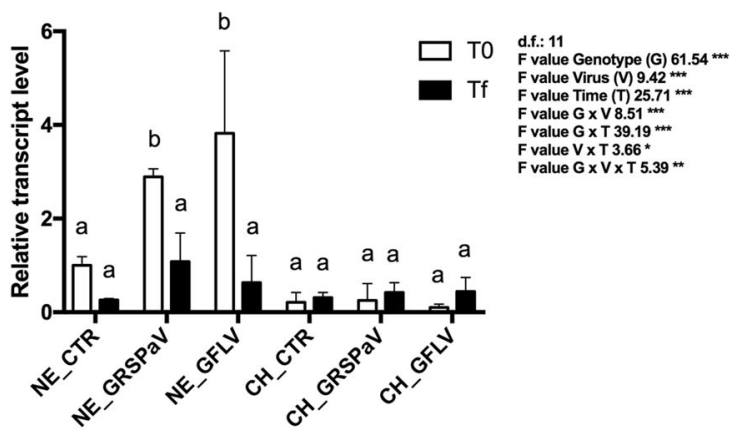

VvPR1_E. necator

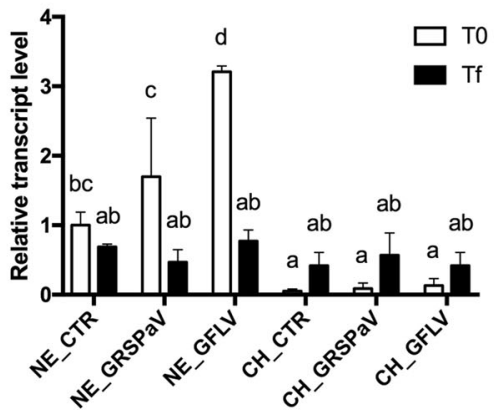

VvMLO6_E. necator

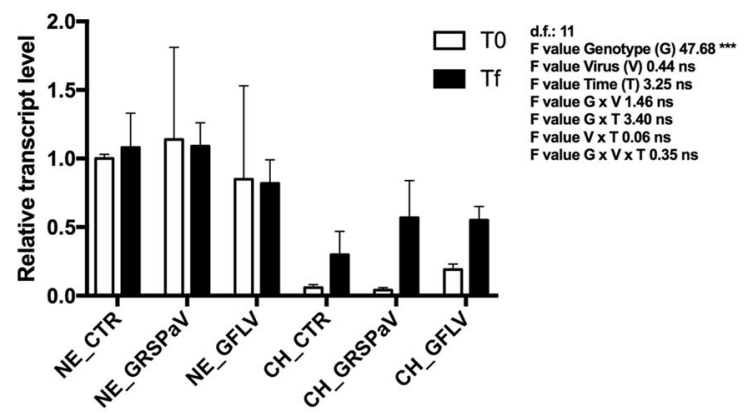

VvßGluc_E. necator

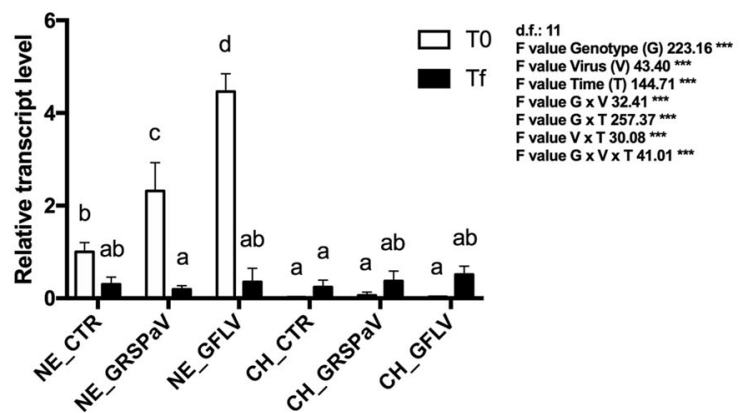

Fig. 2 Relative expression levels of VvPR1 (VIT_03s0088g00700), VvB gluc (VIT_08s0007g06060), and VvMLO6 (VIT_08s0040g02170) measured by quantitative reverse transcription-polymerase chain reaction (RT-qPCR). Samples were collected before inoculation with P. viticola or E. necator (TO) and at the end of experiments (Tf). RT-qPCR signals were normalized to VVAct and VVUBI transcripts. NE_CTR, CH_CTR: virusfree plants; NE_GRSPaV, CH_GRSPaV: GRSPaV-infected plants; NE_GFLV, CH_GFLV: GFLV-infected plants. Data are presented as the mean \pm standard deviation (SD) $(n=3)$. Lowercase letters denote significant differences attested by Tukey's honestly significant difference (HSD) test $(p \leq 0.05)$ 
with respect to the levels observed at T0 (Fig. 2). The expression of mildew resistance locus $\mathrm{O} 6$ ( $V v M L O 6)$, one of the genes linked to $E$. necator susceptibility, was strongly genotype dependent; the higher expression in 'Nebbiolo' at T0 confirmed its higher susceptibility to PM compared to 'Chardonnay' (Table 1). At Tf, expression was stable in 'Nebbiolo', while it increased in 'Chardonnay' regardless of virus or fungal/oomycete infection (Fig. 2).

Another pathway strongly involved in the response to pathogens was found to be carbohydrate metabolism. Sugar transporter 13 (VvSTP13) expression was modulated by the multiple interactions among genotype, time (after $P$. viticola inoculation), and viruses (after E. necator) $(\mathrm{G} \times \mathrm{V} \times \mathrm{T})$. At Tf, expression was higher in 'Chardonnay', particularly in the presence of GRSPaV and GFLV (Fig. 3, Supplementary Table S2). Expression of the sucrose-proton symporter $27(V v S U C 27)$ was regulated differentially following fungal/oomycete inoculation. After inoculation with $P$. viticola, the gene was significantly overexpressed in 'Chardonnay' and downregulated at Tf while, after $E$. necator inoculation, we observed multiple interactions among all components $(\mathrm{G} \times \mathrm{V} \times \mathrm{T})$ with a significant increase in CH_GFLV_TF_En (Fig. 3, Supplementary Table S2). Vacuolar invertase 2 ( VvGIN2) and sucrose synthase (VvSUSY4) showed higher expression levels in 'Nebbiolo' at T0, particularly in the absence of viruses (NE_CTR). Infection by viruses and fungus/ oomycete tended to downregulate these genes in both cultivars (Fig. 3, Supplementary Table S2).

The transcription factor WRKY18 (VvWRKY18), which is involved in activation of stress response pathways, was upregulated at $\mathrm{Tf}$ with a significant $\mathrm{G} \times \mathrm{T}$ interaction (Supplementary Fig. S4, Table S2). Whereas, the NAC domain containing protein 17 ( $V v N A C 17)$, a transcription factor involved in the response to several stressors that improve the efficiency of the enzymatic antioxidant defence system $^{35}$, was upregulated at Tf in virus-infected plants (Supplementary Fig. S4). The 9-cis-epoxycarotenoid dioxygenase $1(V v N C E D 1)$, a key gene in abscisic acid synthesis, was upregulated only at Tf in 'Nebbiolo', particularly after $P$. viticola inoculation, while in 'Chardonnay' was stable under all conditions (Supplementary Fig. S4). Finally, 12oxophytodienoate reductase 3 ( $V v O P R 3)$, a gene linked to jasmonate biosynthesis, had an expression independent on both the genotype and virus infection; it was significantly overexpressed at Tf (Supplementary Fig. S4, Table S2).

The principal component analysis (PCA) of all RT-qPCR data showed division of the samples into three main groups (Fig. 4). Data at T0 were separated from those at Tf in plants inoculated with $P$. viticola and from the data at $\mathrm{Tf}$ in plants inoculated with E. necator. Among the factors that can determine the variability of these data, fungus/oomycete-mediated effects were those that determined the most relevant changes in the transcriptional regulation of selected genes. Only CH_CTR_Tf_EN behaved differently than the other samples infected by E. necator, since it grouped together with the Tf_PV data (Fig. 4).

\section{Discussion}

Set up of the experimental plan to study grapevine-virus interactions in controlled conditions

Over the past decade, studies on plant-virus interactions in grapevine have gained increasing importance ${ }^{5-10,18}$, suggesting that such species may be a suitable woody plant model for studies on this topic ${ }^{11}$. In these works, the molecular, metabolic, and physiological responses to virus infection varied considerably according to the viral strains, presence of multiple viral infections, grapevine genotype, and external environment, including climatic conditions. Starting from these considerations, we set up an experimental design aimed to control some of these variants to better understand whether and which kind of interactions existed between some viruses and $P$. viticola and E. necator, causal agents of DM and PM, respectively, in grapevine. The analyses were focused on GFLV and GRSPaV because both are widespread viruses, well known from the molecular point of view, and represent two extremes of the biological responses induced in grapevine. As a rule, GFLV is quite harmful to grapevine ${ }^{3}$, while GRSPaV is generally latent in $V$. vinifera. On the other hand, positive effects of interactions have been demonstrated in GRSPaV-infected plants subjected to drought ${ }^{18}$.

A critical point in our work was the strong influence of the grapevine genotype, so that healthy controls of the two cultivars, 'Chardonnay' and 'Nebbiolo', had to be produced by somatic embryogenesis ${ }^{36,37}$. These cultivars were chosen for their biological characteristics, e.g. different colour of the berries, different susceptibility to DM and PM, and for their importance and diffusion at international ('Chardonnay') and local levels ('Nebbiolo'). In addition, as somatic embryogenesis may induce somaclonal variation ${ }^{38}$, the genetic uniformity of healthy and infected samples was guaranteed by using one single plant regenerated by a somatic embryo for each cultivar multiplied in vitro and infected with the selected viruses. Considering that the transmission of viruses to grapevine by mechanical inoculation is poor or not efficient at all, the grafting technique was adopted to transmit viruses from infected plants to virus-free 'Chardonnay' and 'Nebbiolo' cultivar.

\section{Changes in virus titre over time}

The experimental plan highlighted the influence of the grapevine genotype and/or of the time factors on viral titre. The viral titre of GRSPaV was similar in 'Nebbiolo' and 'Chardonnay' and decreased at Tf, which is in line with the seasonal variation observed in leaves in the vineyard ${ }^{6}$. Notably, in'Nebbiolo', GFLV titre in leaves was 


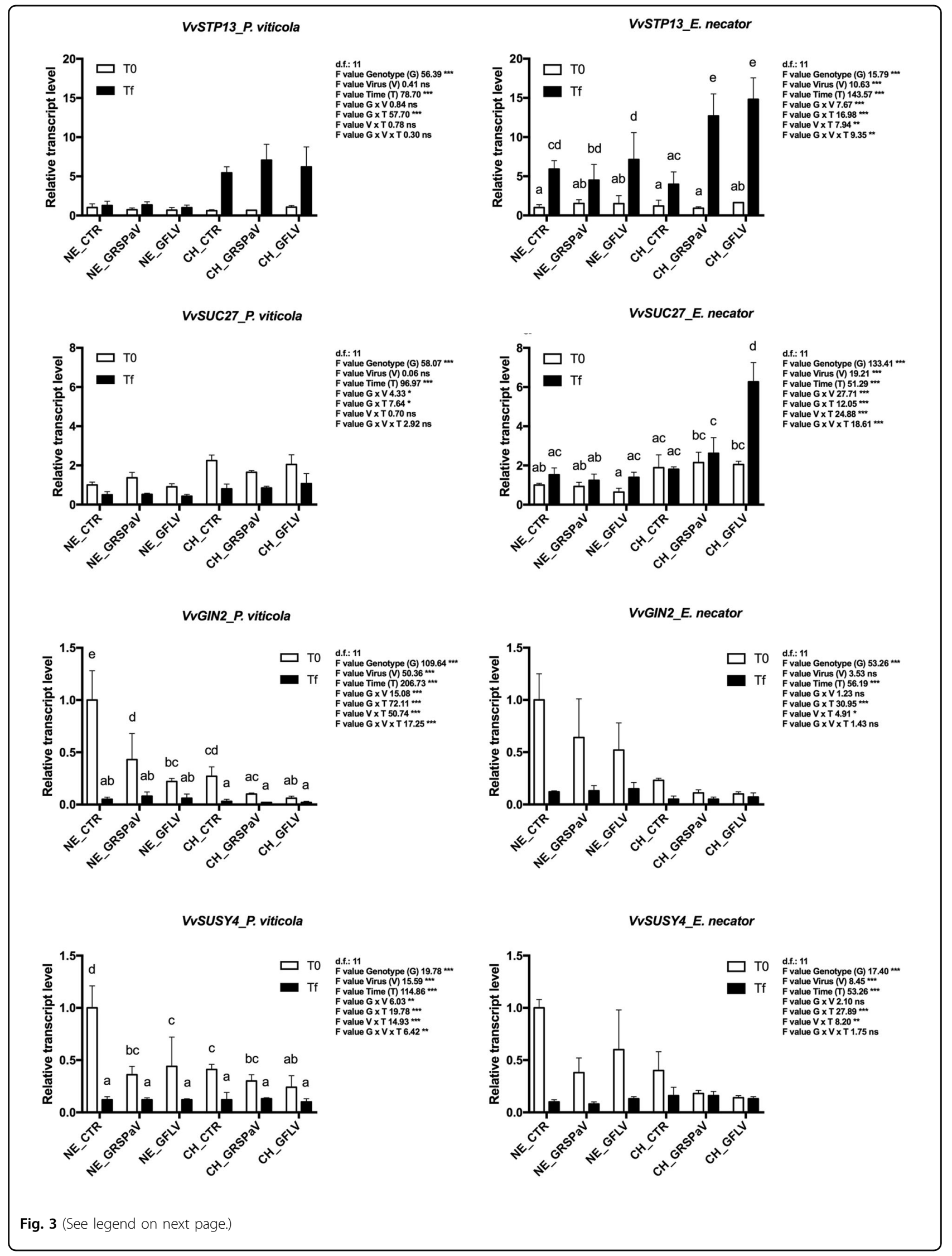


(see figure on previous page)

Fig. 3 Relative expression levels of VvSTP13 (VIT_05s0020g03140), VvSUC27 (VIT_18s0076g00250), VvGIN2 (VIT_02s0154g00090), and VvSUSY4 (VIT_11s0016g00470) measured by quantitative reverse transcription-polymerase chain reaction (RT-qPCR). Samples were collected before inoculation with $P$. viticola or E. necator (TO) and at the end of experiments (Tf). RT-qPCR signals were normalized to VVAct and VVUBI transcripts. NE_CTR, CH_CTR: virus-free plants; NE_GRSPaV, CH_GRSPaV: GRSPaV-infected plants; NE_GFLV, CH_GFLV: GFLV-infected plants. Data are presented as the mean \pm standard deviation (SD) $(n=3)$. Lowercase letters denote significant differences attested by Tukey's honestly significant difference (HSD) test $(p \leq 0.05)$

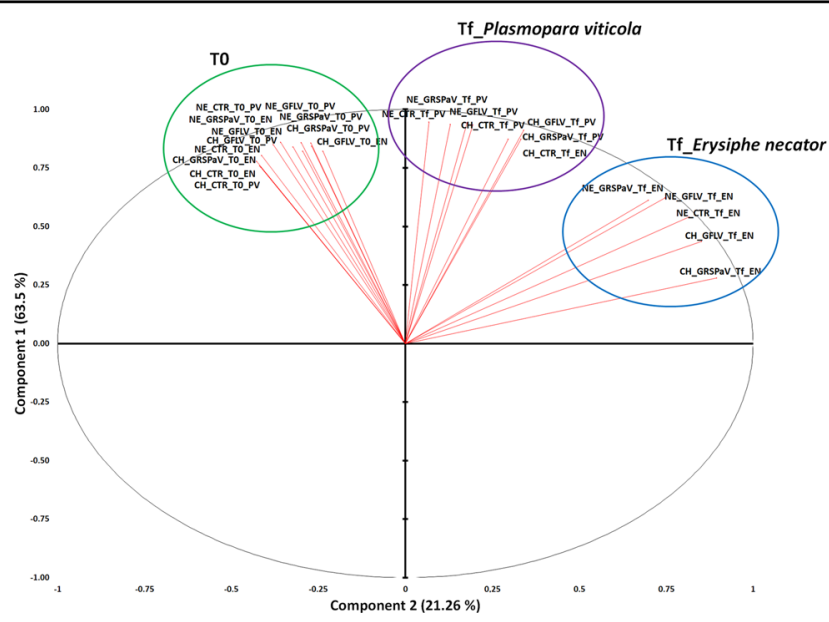

Fig. 4 Principal component analysis (PCA) based on quantitative reverse transcription-polymerase chain reaction (RT-qPCR) values of the candidate genes reported in Table S1 analysed at T0 before inoculation with $P$. viticola (PV) or $E$. necator (EN) and at the end of experiments (Tf). NE_CTR, CH_CTR: virus-free plants; NE_GRSPaV, CH_GRSPaV: GRSPaV-infected plants; NE_GFLV, CH_GFLV: GFLV-infected plants. The first component (vertical) accounts for $63.5 \%$ of the variance and the second component (horizontal) accounts for $21.26 \%$

5-6 times lower than in 'Chardonnay' during the whole sampling time of the experiment (Supplementary Fig. S3), and at $\mathrm{Tf}$ the titre decreased in both cultivars. Krebelj et al. ${ }^{39}$ reported that in vineyards, the highest GFLV titre was observed at the beginning of the vegetative period in May, and that the virus concentration changed in different grapevine cultivar. Our data agree with their study: the lower GFLV concentration at Tf may be considered a seasonal variation of virus titre, although decrease in viral titre may be caused by PM and DM infection. Viral accumulation is also affected by the grapevine genotype because both cultivars were infected with the same GFLV strain but differ in virus titre. Despite the differences in GFLV accumulation between 'Nebbiolo' and 'Chardonnay', no viral symptoms were observed throughout the experiments. This agreed with many years of observation of young potted grapevines in the greenhouse often not exhibiting viral symptoms (Gambino, personal observations).

\section{Powdery and downy mildews development}

Under greenhouse conditions, grapevine-mediated interactions between the two viruses and both the DM and PM causal agents (artificially inoculated) were demonstrated. Although 'Chardonnay' and 'Nebbiolo' showed different susceptibility to these diseases, both cultivars infected with GFLV showed a greater tolerance to PM and DM. These results agree with previous observations, in which grapevines infected by GLRaV-3 in field conditions, were more tolerant to late infection of $P$. viticola ${ }^{19}$. Interestingly, the main differences were observed in the severity of PM and DM diseases. In both cultivars, GRSPaV did not induce significant variation in the development of DM and PM and providing DS and DI values that were generally intermediate between the virus-free controls and GFLV-infected plants. However, in the second trial, GRSPaV seemed to favour the development of DM with DS and DI slightly higher than virus-free controls, even of differences were not significant. Notably, plant responses induced by GRSPaV stimulate tolerance to water stress ${ }^{18}$, whereas they had no effect or worsened the presence to fungal/oomycete pathogens, as shown in this study.

\section{Target plant genes modulation in response to viruses and} powdery and downy mildews

The complex tripartite interactions have not yet been sufficiently explored in terms of molecular and biochemical mechanisms activated to counteract the disease development. Plants evolved several strategies to control 
the immune system responses and limit the costs of resistance ${ }^{40}$. Although poorly explored in grapevine, the simultaneous presence of pathogens can lead the plants to develop a state of readiness or priming that enables earlier, faster and stronger defence responses to a subsequent attack as reported in other plant species ${ }^{41}$. To further explore these aspects, target genes were selected to investigate whether molecular defence priming can be activated in two different grape genotypes.

The first important factor inducing transcriptional modulation of the genes was the time (T0 and Tf) associated with inoculation of DM and PM causal agents. In some genes at $\mathrm{Tf}$, the responses induced by $P$. viticola and $E$. necator were not always in line with the data reported for these pathogens ${ }^{34,42,43}$. This is because we chose to focus on the systemic responses induced by these biotrophic pathogens over a long period by sampling only asymptomatic leaves at $\mathrm{Tf}$ and we did not consider the early molecular responses in infected tissues, which were well characterized in $\mathrm{DM}^{34,42}$ and $\mathrm{PM}^{43}$. An example of this discrepancy was the regulation of $V v P R 1$ and $V v B g l u c$, two genes codifying PR proteins, which are generally upregulated in the first days after the infection of P. viticola ${ }^{42,44}$ and E. necator ${ }^{43,45}$. These genes were downregulated at Tf in 'Nebbiolo' and substantially not modulated in 'Chardonnay', because the acute phase of both pathogen infection disappeared at $\mathrm{Tf}$ and the systemic activation of $V v P R 1$ and $V v B g l u c$ was likely switched off in asymptomatic tissues. This is supported by previous reports in 'Sultana' plants infected by E. necator, in which glucanase activity was concentrated in infected leaf areas, while activity in the uninfected areas of the same leaf was similar to those observed in healthy plants $^{45}$. Stilbene synthases (VvSTSs) showed strong overexpression at $\mathrm{Tf}$ in all cases for both pathogens, and at Tf_EN these genes were expressed 3 to 10 times more than at Tf_PV. Stilbenes are the most important class of phytoalexins, which represent a powerful defence system against several pathogens, including $P$. viticola and $E$. necator $^{34,43,46}$, and are key molecules of basal immunity in grapevine $^{47,48}$. Defense responses involving VvSTSs persisted for a long period after inoculation with both pathogens, with higher levels after E. necator inoculation.

The grapevine genotype represents another relevant factor in the response to $P$. viticola, E. necator and viruses and its effect was evident for some genes at T0. In detail, vacuolar invertase $V v G I N 2$ and $V v P R 1$, and $V v B g l u c$, the genes involved in stress responses, were constitutively expressed more in 'Nebbiolo' than in'Chardonnay', supporting the previous findings on the specific interactions of 'Nebbiolo' with biotic stress ${ }^{49}$. In addition, these genes were strongly overexpressed in 'Nebbiolo' infected by GFLV and GRSPaV, which suggests that these viruses may activate some defence responses that primer plants more promptly to the infection by other pathogens.

The interactions between viruses and grapevine genotype significantly modified the susceptibility reaction of grapes to PM and DM. In carbohydrate metabolism, the expression of $V v G I N 2$ and VvSUSY4 at T0 was downregulated in the presence of viruses, particularly in GFLVinfected plants. The induction of invertases and sucrose synthases can stimulate the change of leaves from source to sink organs ${ }^{50}$ and the accumulation of sugars can lead the plant tissues to host more easily the development of biotrophic pathogens, such as P. viticola and E. necator. Therefore, at $\mathrm{T} 0$, immediately before the fungal/oomycete inoculation, virus-free plants (NE_CTR and $\mathrm{CH}_{-} \mathrm{CTR}$ ) with high expression of $V \nu G I N 2$ and $V \nu S U S Y 4$ seem to be more suitable for the development of these pathogens compared to virus-infected plants, as confirmed by the DS data. At Tf, after inoculation with $P$. viticola and $E$. necator, systemic activation of these genes in asymptomatic leaves was not observed, as conversely reported in symptomatic tissues ${ }^{51}$, suggesting a specific role(s) in symptomatic tissues to counteract pathogen development. The sucrose transporters $V v S T P 13$ and $V v S U C 27$ were upregulated at $\mathrm{Tf}$ after $E$. necator inoculation and, in 'Chardonnay', virus infection significantly increased this upregulation, particularly VvSUC27 in CH_GFLV_Tf_EN. In Arabidopsis, the high constitutive level of STP13 led to an enhanced basal resistance to Botrytis cinerea ${ }^{52}$, while in grapevine, high transcription levels of VvSTP13 were induced by the rootstocks in scions that were more tolerant to $\mathrm{DM}^{53}$. In addition, the transcriptional increase of $V \nu S U C 27$ associated with the downregulation of $V v G I N 2$ is one of the responses observed in the resistant species $V$. amurensis after $P$. viticola inoculation ${ }^{54}$. Therefore, the similar regulation observed in GFLV-infected 'Chardonnay' could partially explain the increased tolerance to DM and PM.

All these findings, at least in our experimental controlled conditions, suggest a virus primed defence state that increases resilience against fungal/oomycete pathogens.

\section{Conclusions}

In this study, infection by GFLV reduced the disease severity caused by $E$. necator and $P$. viticola in grapevine. GFLV infection caused the overexpression of stilbene synthase genes and pathogenesis related proteins (VvPR1, $V v B g l u c)$ and influenced carbohydrate metabolism thus modifying the expression dynamics of sugar transporters (VvSTP13, VvSUC27), vacuolar invertase, and sucrose synthase (VvGIN2 and VvSUSY4) genes. These transcriptional changes can trigger the synthesis of defence compounds, improving the innate plant immune response in grapevine and making the plant prompter to respond to biotic stress. However, this does not appear to be a generic 
reaction to all grapevine viruses, as in GRSPaV-infected plants, the transcriptional modulation of candidate genes was not sufficient to promote protection against E. necator and P. viticola. It is likely that this increased tolerance to fungus/oomycete is an indirect effect of plant responses to viruses, such as GFLV and GLRaV$3^{19}$. Additionally, 'Nebbiolo' showed a higher constitutive expression of some genes in response to pathogen compared to 'Chardonnay', confirming previous observations by Gambino et al. ${ }^{49}$. However, the hypothetical application of GFLV-infected plants within integrated pest management strategies is not feasible, because the GFLV is a harmful virus that must be absent in the grapevine propagation material according to the certification protocols. It will be interesting to broaden our understanding of these interactions which can also be investigated under field conditions for several years, and in the presence of multiple virus and fungal/oomycete infections.

\section{Materials and methods \\ Plant material}

Virus-free plantlets of $V$. vinifera cv. Nebbiolo and Chardonnay were regenerated from somatic embryos obtained from in vitro culture of immature anthers collected in spring (May 2016), according to the previously described protocol $^{36}$. The regenerated plantlets were micropropagated by sub-culturing apical cuttings thus giving rise to individual lines $^{55}$. Virus and viroid infections were assessed by RT-PCR assays as described below. A single virus-free line originated from a single somatic embryo was selected, multiplied, and used for subsequent analyses.

GFLV or GRSPaV were transmitted to virus-free 'Nebbiolo' and 'Chardonnay' lines by in vitro grafting. Woody cuttings from plants infected only by GFLV or GRSPaV were collected during winter and forced to sprout in water at room temperature. Herbaceous green branches (about $5 \mathrm{~cm}$ ) emerging from the buds were collected, surfacesterilized for $15 \mathrm{~min}$ with sodium hypochlorite $(1.5 \%$ available chlorine) and rinsed several times with sterile distilled water. Ten apical cuttings ( $3-4 \mathrm{~cm}$ long) for each virus-free line were grafted on virus-infected herbaceous green branches and maintained under in vitro conditions. After 1 month, the virus infection was assessed by RTPCR and a single apical cutting of 'Nebbiolo' and 'Chardonnay' infected by GFLV or GRSPaV were micropropagated by repetitively sub-culturing apical cuttings.

For each thesis, 'Nebbiolo' and 'Chardonnay' virus-free (NE_CTR, CH_CTR), infected by GFLV (NE_GFLV, CH_GFLV), and infected by GRSPaV (NE_GRSPaV, CH_GRSPaV), 16 plantlets were acclimated out of in vitro conditions in 1 litre pots $(10 \times 10 \times 12 \mathrm{~cm})$ using a peat substrate (TS4, Turco Silvestro, Italy) and placed in the greenhouse (Supplementary Fig. S1).

\section{Virus detection}

The major viruses and viroids commonly present in wine grape cultivar grown in north western Italy are GFLV, GVB, grapevine fleck virus (GFkV), grapevine leafroll associated virus-1, -2, -3 (GLRaV-1, -2, -3), grapevine-virus A (GVA), arabis mosaic virus (ArMV) and GRSPaV. These viruses were detected by multiplex RT-PCR reported in Gambino ${ }^{56}$, as well as grapevine pinot gris virus (GPGV) following the protocol of Glasa et al. ${ }^{57}$. Multiplex RT-PCR assays reported by Hajizadeh et al. ${ }^{58}$ were adopted for the detection of five viroids: hop stunt viroid (HSVd), grapevine yellow speckle viroid 1 and 2 (GYSVd-1, -2), australian grapevine viroid (AGVd), and citrus exocortis viroid (CEVd). One accession of 'Nebbiolo', originally infected by GFLV and GRSPaV, was previously subjected to sanitation. The in vitro thermotherapy and meristem tip culture sanitation techniques were used to eliminate GFLV from some explants and GRSPaV from other ones, thus obtaining some lines still infected by only one of these two viruses, as confirmed by RT-PCR. The two plants were used for the grafting experiments described above.

To characterize the isolates of the two viruses, RT-PCR amplification products were purified and sequenced by Sanger sequencing, as reported previously ${ }^{49}$. PCR was carried out using Phusion Hot Start II High-Fidelity DNA Polymerase (Thermo Fisher Scientific, Waltham, MA USA) according to manufacturer's instructions. For GFLV, primers GFLVpoly5238Fw and GFLVpoly6048Rev reported by Pacifico et al. $^{33}$ targeting $829 \mathrm{bp}$ of the putative RNA-dependent RNA polymerase (RdRp) $\left(1 \mathrm{E}^{\mathrm{Pol}}\right)$ gene localized in RNA1 of the virus were used (Supplementary Table S1). For GRSPaV, primers RSP35 and RSP36 $^{31}$ targeting $476 \mathrm{bp}$ of the genomic region encoding the $\mathrm{RdRp}$ domain were used (Supplementary Table S1). A total of 107 sequences of GFLV RNA1 and 123 sequences of GRSPaV were deposited in GenBank (National Center for Biotechnology Information, NCBI) and aligned with the respective 'Nebbiolo' isolates using Multiple Sequence Alignment (MUSCLE, https://www.ebi.ac.uk/Tools/msa/ muscle/). Phylogenetic analysis based on the neighbourjoining (NJ) method (with bootstrap values of 1000 replicates) was carried out using MEGAX software version $10.1 .7^{59}$.

\section{Experimental layout and inoculation of $P$. viticola and $E$. necator}

Two independent trials were carried out in the greenhouse at the University of Turin, Agroinnova Competence Center, located in Grugliasco, in the Northwest of Italy (GPS: 45 $05^{\prime} 57.8^{\prime \prime} \mathrm{N}, 7^{\circ} 35^{\prime} 29.5^{\prime \prime} \mathrm{E}$ ) in summer 2018 and 2019. For each trial and pathogen ( $P$. viticola and $E$. necator), four replicates (two plant/replicate) with a randomized block design were used for each infected or 
virus-free plant for both genotypes. Three months after growing in greenhouse conditions, the plants were artificially inoculated with $P$. viticola and $E$. necator collected in Piedmont (Northern Italy). The infected leaves with $P$. viticola from 'Chardonnay' plants and of $E$. necator from 'Moscato' plants were shaken in $100 \mathrm{ml}$ of sterile deionized water, and each suspension obtained was adjusted, with the aid of a haemocytometer, to $5 \times 10^{3}$ sporangia $/ \mathrm{ml}$ and $1 \times 10^{4}$ conidia/ml, respectively. The artificial inoculation of the pathogens was carried out for each trial throughout nebulisation with a laboratory spray bottle ( $10 \mathrm{ml}$ of capacity) of one $\mathrm{ml}$ of suspensions/ plant. All plants artificially inoculated with $P$. viticola or $E$. necator were maintained in two different greenhouse compartments in order to avoid cross contamination, at temperatures ranging from 20 and $25^{\circ} \mathrm{C}$ and relative humidity maintained close to $85-90 \%$ for $P$. viticola and $25-27^{\circ} \mathrm{C}$ for $E$. necator without overhead irrigation. The dates of the different operations carried out are reported under Supplementary Table S3.

About 10-25 leaves/plant were visually estimated by rating the percentage of affected leaves (disease incidence, DI) for both pathogens. The leaf area affected by the pathogen (disease severity, DS) was estimated using the severity scale $1-7$ corresponding to $1=$ no symptoms; $2<$ $5 \% ; 3=5-10 \% 4=10-25 \% ; 5=25-50 \% ; 6=50-75 \%$ and $7>75 \%$ as reported by the EPPO / OEPP protocols for $P$. viticola (PP 1.31) or E. necator (PP1.4) by visually check 10 to 25 leaves / plant for each plant. DS was calculated using the formula: $\Sigma$ (number of leaves $\times$ rating scale $0-7$ ) / (total number of recorded leaves).

\section{Quantitative RT-PCR analysis}

Fifteen genes representative of the most important molecular pathways involved in the response to biotic agents in grapevine were analysed (Supplementary Table S1). In the second fungal/oomycete inoculation trial in 2019, for each cultivar ('Nebbiolo' and 'Chardonnay'), viral condition (CTR not infected, GFLV-infected plants, and GRSPaV-infected plants), and fungal/oomycete inoculated (P. viticola and $E$. necator), leaves were collected before the fungal inoculation (T0) and on the day of the final assessment of DS and DI of fungal/oomycete diseases (Tf) from three biological replicates for a total of 72 samples (2 genotypes $\times 3$ viral conditions $\times 2$ fungal/oomycete pathogen $\times 2$ collections $\times 3$ biological replicates) (Supplementary Fig. S1). For each biological replicate, fully developed leaves (without fungal symptoms for the Tf) in the middle of shoots were collected from two or three plants and stored at $-80^{\circ} \mathrm{C}$. Total RNA was extracted using the rapid CTAB method ${ }^{60}$ and RNA quantity and quality were checked using a NanoDrop 1000 spectrophotometer (Thermo Fisher Scientific, Waltham, MA, USA). DNase treatment, first-strand cDNA synthesis, and real-time PCR were carried out as reported by Chitarra et al. ${ }^{53}$. The results were calculated as expression ratios (relative quantity, RQ) relative to NE_CTR at T0.

Relative quantification of GFLV and GRSPaV were carried out on leaves collected at T0 and Tf using primers designed with viral RdRp (Supplementary Table S1) and following the same procedure reported above.

\section{Statistical analyses}

DI and DS were analyzed using spss software 26 . The DI and DS data were subjected to Levene's test to determine the homogeneity of the variance and to Shapiro-Wilk test to check the normality. When necessary DI and DS data, were arc-sin-transformed to stabilize the variances and normalize their distribution. The General linear model analysis was conducted to test for the effect of each factor (genotype and virus infection), and their interactions on DI and DS. When the effects of the tested factors were significant $(p \leq 0.05)$ and interactions were observed among the considered factors, the means were separated by Tukey's honestly significant difference test (HSD) at $p \leq 0.05$.

For RT-qPCR data, when ANOVA indicated that either genotype (NE, $\mathrm{CH})$, virus (CTR, GRSPaV, GFLV), and time (T0, Tf) factors or their interaction was significant, mean separation was performed using the Tukey's HSD test at a probability level of $p \leq 0.05$. The standard deviation (SD) of all means were calculated.

\section{Acknowledgements}

This research was financially supported by the SAFEGRAPE project (Sustainable grapevine protection against fungal pathogens) funded by Fondazione Cassa di Risparmio di Cuneo. The authors wish to thank Professor Maurizio Conti for critical reading of the manuscript.

\section{Author details \\ ${ }^{1}$ Centre of Competence for the Innovation in the Agro-Environmental sector (AGROINNOVA), University of Torino, Largo Paolo Braccini 2, 10095 Grugliasco, Italy. ${ }^{2}$ Institute for Sustainable Plant Protection, National Research Council (IPSP-CNR), Strada delle Cacce 73, 10135 Torino, Italy. ${ }^{3}$ Research Centre for Viticulture and Enology, Council for Agricultural Research and Economics (CREA-VE), Via XXVIII Aprile 26, 31015 Conegliano, Italy. ${ }^{4}$ Department of Agricultural, Forest and Food Sciences (DISAFA), University of Torino, Largo Paolo Braccini 2, 10095 Grugliasco, Italy}

\section{Author contributions}

G.Gi. performed the fungus/oomycete experiments in greenhouse, estimated and analysed the data and contributed to write the article; W.C. performed statistical analyses and complemented the writing; A.M. and P.B. carried out the molecular analyses; M.M. supervised the experiments, supported the evaluation of diseases and revised the manuscript; M.P. and M.L.G conceived the project and revised the manuscript; G.Ga. conceived the project,

supervised the experiments, wrote the article and revised the manuscript. All authors read and approved the manuscript.

\section{Data availability}

The sequences of the virus isolates used in this study are available at NCBI accession numbers MN889892 (GRSPaV_NE) and MN889891 (GFLV_NE).

Conflict of interest

The authors declare that they have no conflict of interest. 
Supplementary Information accompanies this paper at (https://doi.org/ 10.1038/s41438-020-00413-x).

Received: 7 August 2020 Revised: 15 September 2020 Accepted: 17 September 2020

Published online: 01 November 2020

\section{References}

1. Pearson, R. C. \& Goheen, A. C. (eds) Compendium of Grape Diseases (American Phytopathological Society, St. Paul, MN, 1988)

2. Martelli, G. P. Where grapevine virology is heading to. In Proc. 19th Congress of International Council for the Study of Viruses and Virus-lile Diseases of the Grapevine (eds Fiore, N. \& Zamorano Carrasco, A.) 10-15 (University of Chile, Chile, 2018).

3. Martelli, G. P. An overview on grapevine viruses, viroids, and the diseases they cause. In Grapevine Viruses: Molecular Biology, Diagnostics and Management (eds Meng, B., Martelli, G., Golino, D. \& Fuchs, M.) 31-46 (Springer, Cham, Switzerland, 2017)

4. Sanfaçon, $H$. et al. Secoviridae: a proposed family of plant viruses within the order Picornavirales that combines the families Sequiviridae and Comoviridae, the unassigned genera Cheravirus and Sadwavirus, and the proposed genus Torradovirus. Arch. Virol. 154, 899-907 (2009).

5. Vega, A., Gutiérrez, R. A., Peña-Neira, A., Cramer, G. R. \& Arce-Johnson, P. Compatible GLRaV-3 viral infections affect berry ripening decreasing sugar accumulation and anthocyanin biosynthesis in Vitis vinifera. Plant Mol. Biol. 77, 261-274 (2011)

6. Gambino, G. et al. Co-evolution between Grapevine rupestris stem pittingassociated virus and Vitis vinifera $L$. leads to decreased defence responses and increased transcription of genes related to photosynthesis. J. Exp. Bot. 63 , 5919-5933 (2012)

7. Endeshaw, S. T., Sabbatini, P., Romanazzi, G., Schilder, A. C. \& Neri, D. Effects of grapevine leafroll associated virus 3 infection on growth, leaf gas exchange, yield and basic chemistry of Vitis vinifera L. cv. Cabernet Franc. Sci. Hortic. 170, 228-236 (2014)

8. Montero, R. et al. Alterations in primary and secondary metabolism in Vitis vinifera 'Malvasia de Banyalbufar' upon infection with Grapevine Leafroll associated Virus 3 (GLRaV-3). Physiol. Plant. 157, 442-452 (2016).

9. Chitarra, W. et al. Dissecting interplays between Vitis vinifera $\mathrm{L}$. and grapevine virus B (GVB) under field conditions. Mol. Plant Pathol. 19, 2651-2666 (2018).

10. Tobar, M. et al. Divergent molecular and growth responses of young "Cabernet Sauvignon" (Vitis vinifera) plants to simple and mixed infections with Grapevine rupestris stem pitting-associated virus. Hortic. Res. 7, 2 (2020).

11. Perrone, I., Chitarra, W., Boccacci, P. \& Gambino, G. Grapevinevirus-environment interactions: an intriguing puzzle to solve. New Phytol. 213 983-987 (2017)

12. Roossinck, M. J. The good viruses: viral mutualistic symbioses. Nat. Rev Microbiol. 9, 99-108 (2011)

13. Hily, J. M., Poulicard, N., Mora, M. A., Pagán, I. \& García-Arenal, F. Environment and host genotype determine the outcome of a plant-virus interaction: From antagonism to mutualism. New Phytol. 209, 812-822 (2016).

14. Xu, P. et al. Virus infection improves drought tolerance. New Phytol. 180 911-921 (2008).

15. Márquez, L. M., Redman, R. S., Rodriguez, R. J. \& Roossinck, M. J. A virus in a fungus in a plant: three-way symbiosis required for thermal tolerance. Science 315, 513-515 (2007)

16. Shapiro, L. R. et al. Disease interactions in a shared host plant: effects of preexisting viral infection on cucurbit plant defense responses and resistance to bacterial wilt disease. PloS ONE 8, e77393 (2013).

17. Aguilar, E. et al. Virus infection induces resistance to Pseudomonas syringae and to drought in both compatible and incompatible bacteria-host interactions, which are compromised under conditions of elevated temperature and $\mathrm{CO}_{2}$ levels. J. Gen. Virol. 101, 122-135 (2020).

18. Pantaleo, $V$. et al. Novel functional microRNAs from virus-free and infected Vitis vinifera plants under water stress. Sci. Rep. 6, 20167 (2016).

19. Repetto, O. et al. Low susceptibility of grapevine infected by GLRaV-3 to late Plasmopara viticola infections: towards understanding the phenomenon. Physiol. Mol. Plant Pathol. 79, 55-63 (2012).

20. Dicke, M. Plant phenotypic plasticity in the phytobiome: a volatile issue. Curr Opin. Plant. Biol. 32, 17-23 (2016).
21. Arens, K. Untersuchungen über Keimung und Zytologie der Oosporen von Plasmopara viticola (Berl. et De Toni). Jahrbücher Wissenschaftliche Botanik 70, 57-92 (1929)

22. Pons, A. et al. Impact of Plasmopara viticola infection of Merlot and Cabernet Sauvignon grapes on wine composition and flavor. Food Chem. 239, 102-110 (2018).

23. Calonnec, A., Cartolaro, P., Poupot, C., Dubourdieu, D. \& Darriet, P. Effect of Uncinula necatrix on the yield and quality of grapes (Vitis vinifera) and wine. Plant Pathol. 53, 434-445 (2004).

24. Komarek, M., Cadkova, E., Chrastny, V., Bordas, F. \& Bollinger, J. C. Contamination of vineyard soils with fungicides: a review of environmental and toxicological aspects. Environ. Int. 36, 138-151 (2010)

25. Tsakirakis, A. N. et al. Dermal \& inhalation exposure of operators during fungicide application in vineyards. Evaluation of coverall performance. Sci. Total Environ. 470-471, 282-289 (2014).

26. Provost, C. \& Pedneault, K. The organic vineyard as a balanced ecosystem: Improved organic grape management and impacts on wine quality. Sci. Hortic. 208, 43-56 (2016).

27. Gadoury, D. M. et al. Grapevine powdery mildew (Erysiphe necatrix): a fascinating system for the study of the biology, ecology and epidemiology of an obligate biotroph. Mol. Plant Pathol. 13, 1-16 (2012)

28. Company, S. et al. Use of beneficial bacteria and their secondary metabolites to control grapevine pathogen diseases. BioControl 58, 435-455 (2013).

29. Gutiérrez-Gamba, G., Romanazzi, G., Garde-Cerdàn, T. \& Pérez-Alvarez, E. P. A review of the use of biostimulants in the vineyard for improved grape and wine quality: effects on prevention of grapevine diseases. J. Sci. Food Agric. 99, 1001-1009 (2019).

30. Rantsiou, K. et al. Impact of chemical and alternative fungicides applied to grapevine cv Nebbiolo on microbial ecology and chemical-physical grape characteristics at harvest. Front. Plant Sci. 11, 700 (2020).

31. Terlizzi, F. et al. Detection of multiple sequence variants of Grapevine rupestris stem pitting-associated virus using primers targeting the polymerase domain and partial genome sequencing of a novel variant. Ann. Appl. Biol. 159 478-490 (2011)

32. Meng, B. \& Rowhani, A. Grapevine rupestris stem pitting-associated virus. In Grapevine Viruses: Molecular Biology, Diagnostics and Management (eds Meng, B., Martelli, G., Golino, D. \& Fuchs, M.) 257-287 (Springer, Cham, Switzerland, 2017)

33. Pacifico, D., Caciagli, P., Palmano, S., Mannini, F. \& Marzachì, C. Quantitation of grapevine leafroll associated virus-1 and -3, Grapevine virus A, Grapevine fanleaf virus and Grapevine fleck virus in field-collected Vitis vinifera L. 'Nebbiolo' by real-time reverse transcription-PCR. J. Virol. Methods 172, 1-7 (2011)

34. Ciaffi, M. et al. Transcriptional regulation of stilbene synthases in grapevine germplasm differentially susceptible to downy mildew. BMC Plant Biol. 19, 404 (2019).

35. Ju, Y. L. et al. VVNAC17, a novel stress-responsive grapevine (Vitis vinifera L.) NAC transcription factor, increases sensitivity to abscisic acid and enhances salinity, freezing, and drought tolerance in transgenic Arabidopsis. Plant Physiol. Biochem. 146, 98-111 (2020).

36. Gambino, G, Bondaz, J. \& Gribaudo, I. Detection and elimination of viruses in callus, somatic embryos and regenerated plantlets of grapevine. Eur. J. Plant Pathol. 114, 397-404 (2006)

37. Gambino, G., Navarro, B., Vallania, R., Gribaudo, I. \& Di Serio, F. Somatic embryogenesis efficiently eliminates viroid infections from grapevines. Eur. J. Plant Pathol. 130, 511-519 (2011)

38. Dalla Costa, L., Malnoy, M. \& Gribaudo, I. Breeding next generation tree fruits: technical and legal challenges. Hortic. Res. 4, 17067 (2017).

39. Krebelj, A. J., Čepin, U., Ravnikar, M. \& Novak, M. P. Spatio-temporal distribution of Grapevine fanleaf virus (GFLV) in grapevine. Eur. J. Plant Pathol. 142 159-171 (2015)

40. Karasov, T. L, Chae, E, Herman, J. J. \& Bergelson, J. Mechanisms to mitigate the trade-off between growth and defense. Plant Cell 29, 666-680 (2017).

41. Hilker, M. et al. Priming and memory of stress responses in organisms lacking a nervous system. Biol. Rev. 91, 1118-1133 (2016).

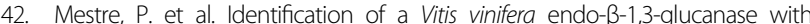
antimicrobial activity against Plasmopara viticola. Mol. Plant Pathol. 18, 708-719 (2017)

43. Fung, R. W. et al. Powdery mildew induces defense-oriented reprogramming of the transcriptome in a susceptible but not in a resistant grapevine. Plant Physiol. 146, 236-249 (2008) 
44. Liu, S. L. et al. Response of phytohormones and correlation of SAR signal pathway genes to the different resistance levels of grapevine against Plasmopara viticola infection. Plant Physiol. Biochem. 107, 56-66 (2016).

45. Jacobs, A. K., Dry, I. B. \& Robinson, S. P. Induction of different pathogenesisrelated CDNAs in grapevine infected with powdery mildew and treated with ethephon. Plant Pathol. 48, 325-336 (1999).

46. Schnee, S., Viret, O. \& Gindro, K. Role of stilbenes in the resistance of grapevine to powdery mildew. Physiol. Mol. Plant Pathol. 72, 128-133 (2008).

47. Figueiredo, A. et al. Transcriptional and metabolic profiling of grape (Vitis vinifera $\mathrm{L}$.) leaves unravel possible innate resistance against pathogenic fungi. J. Exp. Bot. 59, 3371-3381 (2008).

48. Shi, J. et al. The comparative analysis of the potential relationship between resveratrol and stilbene synthase gene family in the development stages of grapes (Vitis quinquangularis and Vitis vinifera). Plant Physiol. Biochem. 74, 24-32 (2014).

49. Gambino, G. et al. Whole-genome sequencing and SNV genotyping of 'Nebbiolo' (Vitis vinifera L.) clones. Sci. Rep. 7, 17294 (2017).

50. Kühn, C. \& Grof, C. P. Sucrose transporters of higher plants. Curr. Opin. Plant Biol. 13, 288-298 (2010).

51. Hayes, A., Feechan, A. \& Dry, I. B. Involvement of abscisic acid in the coordinated regulation of a stress-inducible hexose transporter (VHT5) and a cell wall invertase in grapevine in response to biotrophic fungal infection. Plant Physiol. 153, 211-221 (2010).
52. Lemonnier, P. et al. Expression of Arabidopsis sugar transport protein STP13 differentially affects glucose transport activity and basal resistance to Botrytis cinerea. Plant Mol. Biol. 85, 473-484 (2014).

53. Chitarra, W. et al. Grapevine grafting: scion transcript profiling and defenserelated metabolites induced by rootstocks. Front. Plant Sci. 8, 654 (2017).

54. Cai, Y. et al. Sucrose transporters of resistant grapevine are involved in stress resistance. Plant Mol. Biol. 100, 111-132 (2019).

55. Gribaudo, I., Gambino, G., Cuozzo, D. \& Mannini, F. Attempts to eliminate Grapevine rupestris stem pitting-associated virus from grapevine clones. J. Plant Pathol. 88, 293-298 (2006).

56. Gambino, G. Multiplex RT-PCR method for the simultaneous detection of nine grapevine viruses. In Plant Virology Protocols, Methods in Molecular Biology Vol. 1236 (eds Uyeda, I. \& Masuta, C.) 39-47 (Springer, 2015).

57. Glasa, M. et al. Molecular characterization of divergent Grapevine Pinot gris virus isolates and their detection in Slovak and Czech grapevines. Arch. Virol. 159, 2103-2107 (2014).

58. Hajizadeh, M., Navarro, B., Bashir, N. S., Torchetti, E. M. \& Di Serio, F. Development and validation of a multiplex RT-PCR method for the simultaneous detection of five grapevine viroids. J. Virol. Methods 179, 62-69 (2012).

59. Kumar, S., Stecher, G., Li, M., Knyaz, C. \& Tamura, K. MEGA X: molecular evolutionary genetics analysis across computing platforms. Mol. Biol. Evol. 35 1547-1549 (2018).

60. Gambino, G., Perrone, I. \& Gribaudo, I. A rapid and effective method for RNA extraction from different tissues of grapevine and other woody plants. Phytoch. Anal. 19, 520-525 (2008). 